\title{
Causes of Low Double-flowered Seed Production in Breeding Zinnia
}

\author{
Daiichiro Miyajima \\ Faculty of Agriculture, Shinshu University, Kamiinagun, Nagano, 399-45 Japan \\ Additional index words. inflorescence morphology, pollination, Zinnia violacea
}

\begin{abstract}
The causes of low production of seeds capable of producing double-flowered plants and of high production of seeds capable of producing single-flowered plants were investigated in zinnias (Zinnia violaceu Cav.). Poor pollination was a major cause of the low seed set. A tubular floret produced abundant pollen; however, the pollen flow to ray stigmas was limited due to the infrequent visitation by pollinators. Moreover, in the double-flowered capitula, newly opened ray petals overlapped on the pistils that unfolded the previous day. These phenomena were considered to cause low seed set in double-flowered plants. Actually, capitula with more tubular florets produced more seeds than those with fewer tubular florets. Pollen germination and plants near zinnias had additional possible influences on seed production of double-flowered zinnias.
\end{abstract}

Seed production of double-flowered zinnias by open pollination has two serious problems: low seed set and an increase in the rate of seeds that have single-flowered capitula (Okada, 195 1). The composition of the capitula is a major cause of these problems (Miyajima and Nakayama, 1994). Ornamentally superior capitula of double-flowered zinnias have more ray florets (female) and fewer tubular florets (male + female) than the ornamentally inferior capitula of single-flowered zinnias. Based on this relationship, seed set would decrease due to the limited pollen supply if severe rogueing is done to eliminate the genes for a single-flowered capitulum. Conversely, seeds for single-flowered capitula would increase if many single-flowered capitula are permitted to survive for seed yield. Thus, the two problems are closely related. The objectives of the present study were to find the additional causes of these two related problems. In the first place, I wanted to demonstrate that the low seed set was mainly the result of poor pollination rather than failure of fertilization. Second, I investigated factors that served as barriers to pollination, including differences in insect visitation between tubular and ray florets and the physical barrier to pollination of the ray pistils. Third, I assessed the relationship of the rate or the number of the two types of florets in a capitulum to the seed production of the capitulum. Fourth, I wanted to document if some plant species that were planted or casually grew near zinnias affected the seed production of zinnias by competing for pollinators.

\section{Materials and Methods}

This study was conducted at the farm of the Faculty of Agriculture of Shinshu Univ., Nagano Prefecture, Japan, in 1992 and 1993. Cultivars used were 'Kumamotonokagayaki', pumila double (Takii Seed Corp., Kyoto); 'Goldenball', pumila double (Takii); 'Snowball', pumila double (Sakata Seed Corp., Kanagawa); and 'Purple zem', pompon (Sakata). These cultivars were seeded in a medium consisting of 1 peat moss : 1 sand : 1 kuroboku soil (volcanic ash soil) (by volume) with a $14 \mathrm{~N}-5.2 \mathrm{P}-11.6 \mathrm{~K}$ coated fertilizer (8 g.liter') in polyethylene pots $(15 \mathrm{~cm}$ in diameter and $12 \mathrm{~cm}$ tall) on 28 Apr. 1992 and on 6 Apr. 1993. The plants were thinned to one per pot. A $14 \mathrm{~N}-2.2 \mathrm{P}-5.8 \mathrm{~K}$ liquid fertilizer $\left(5 \mathrm{~g} \cdot\right.$ liter $\left.^{-1}\right)$ was applied to the plants once a week after emergence.

Received for publication 6 Feb. 1995. Accepted for publication 19 Apr. 1995. The cost of publishing this paper was defrayed in part by the payment of page charges. Under postal regulations, this paper therefore must be hereby marked advertisement solely to indicate this fact.
Seedlings were planted in the field or in plastic-film greenhouses, with $0.8 \mathrm{~m}$ between seedlings in a row and $1.0 \mathrm{~m}$ between rows for each cultivar. A $14 \mathrm{~N}-5.2 \mathrm{P}-11.6 \mathrm{~K}$ coated fertilizer $\left(150 \mathrm{~g} \cdot \mathrm{m}^{-1}\right)$ was preplant-broadcast and incorporated before planting. The sides of the greenhouse were open throughout the study (temperature range, 10 to $35 \mathrm{C})$. In the field, the shortest distance between cultivars was $>10 \mathrm{~m}$.

Longevity of unpollinated pistils and seed set of ray florets pollinated by hand. Ten plants each of 'Kumamotonokagayaki', 'Snowball', and 'Purple zem' in the greenhouses were used to determine the longevity of the unpollinated pistil. In the early morning of the first day of capitulum flowering, ray petals of flowers were marked to distinguish them from florets that flowered later. Capitula were bagged using paper bags. To lessen the influence of bagging, the paper bags were removed 5 days after bagging. At that time, the petals of flowers that appeared afterward had fully overlapped the pistils produced. The days to withering were determined by daily observation. The seed set of pollinated ray florets in the greenhouses was determined in three identical cultivars. Petals were marked and the capitula were bagged as previously described. Marked ray florets were cross pollinated. Pollen grains collected from many plants were mixed before pollination to avoid pollination within self-incompatible lines. Paper bags on the capitula pollinated $\geq 6$ days after pistil unfolding were removed 5 days after bagging. Ten capitula with more than ten marked ray florets per capitulum from ten separate plants per cultivar were used to determine the seed set for each day from pistil unfolding to pollination. Seed set was checked 2 weeks after pollination in each capitulum. Seed set of the capitulum was defined as the number of florets that set seeds/number of florets pollinated in a capitulum $\times 100$. The longevity of the unpollinated pistils was compared among the cultivars by Scheffe's method (Sokal and Rohlf, 1981). The variation in days from pistil unfolding to pollination (seed set) was analyzed by the two-way analysis of variance (ANOVA) of a fixed model after arcsin transformation.

Number of pollen grains per tubular floret and pollen-ovule ratio. Pollen grains of 10 tubular florets from 10 plants of each of the three identical cultivars in the above study were counted with a microscope $(100 \times)$ (Optiphoto2; Nikon, Tokyo). Pollen grain numbers were compared among cultivars by Scheffe's method. The pollen-ovule ratio (pollen grain number per ovule) was calculated using the data for the ovule number in a previous report (Miyajima and Nakayama, 1994) because the pollen grain and ovule numbers were obtained from identical zinnia populations.

Pollen germination. Pollen grains were collected from five 
plants each of 'Kumamotonokagayaki', 'Goldenball', and 'Purple zem' grown in plastic-film greenhouses. The percentage germination of pollen grains was assessed six times at 5-day intervals in August using $20 \%$ gelatin media containing $20 \%$ sucrose and $0.2 \%$ $\mathrm{Na}_{2} \mathrm{~B}_{4} \mathrm{O}_{7} \cdot 10 \mathrm{H}_{2} \mathrm{O}$ (unpublished data). The germinating pollen grains were randomly counted with a microscope $(100 \times)$ at three sites on the media with $>100$ pollen grains per site after at least $2 \mathrm{~h}$ of incubation. A pollen grain was considered to have germinated when the length of the pollen tube was equal to or longer than the diameter of the grain. Data were analyzed by the three-way ANOVA (fixed effects of cultivars and random effects of pollen collection dates and individual plants) after arcsin transformation.

Insect visits to ray and tubular florets. Among the insect species that visited zinnias in the field frequently were Apis mellifera (honeybee) and Eristulomyia tenax (dronefly). In September, the visits per hour of a honeybee or a dronefly to the ray and tubular florets of 'Kumamotonokagayaki' were counted and the landing time per visit was measured between 1000 and 1100 HR over 2 days for each insect. Landing time was measured without considering the time taken for pollen or nectar collection. At the beginning of measurement, an insect to be measured was chosen at random. In case the insect was lost, another insect was then chosen. The difference in the number of visits per hour and the landing time per visit of the two insect species between ray and tubular florets was tested by the chi-square test for goodness of fit and the MannWhitney test, respectively.

Pollen loud of ray florets. On 4 sunny days with a maximum wind velocity of $<5 \mathrm{~m} \cdot \mathrm{s}^{-1}$ (31 Aug. and 4, 7, and 9 Sept.), the capitula of 'Kumamotonokagayaki', 'Snowball', and 'Purple zem' opened up by $0900 \mathbf{H R}$. Five capitula of each of the three cultivars with > 20 ray florets and no tubular florets per capitulum were collected at $1600 \mathrm{HR}$. They were positioned at the top of each plant (without the possibility of attachment of fallen pollen from other capitula). The pollen grains on the stigmas were counted using a microscope $(100 \times)$ and the grains present on a single stigma were graded as zero, one to nine, and more than nine. The percentages of stigmas for each of the three grades of pollen numbers were then calculated. Differences among collection date and cultivar were evaluated by the chi-square test for independence.

Overlapping of petals on pistils. Photographs of a singleflowered and double-flowered capitulum were taken daily from the day of capitulum anthesis to show the difference in the overlapping of petals on pistils between the two capitulum types.

Seed production in two types of florets of open-pollinated plants. With the beginning of flowering in capitula of 'Kumamotonokagayaki', each capitulum was tagged and the dates of opening of the first floret were recorded. These capitula were subjected to open-pollination. More than 50 days after opening, 115 capitula were harvested. No more than two capitula were harvested from a plant. The number of mature seeds formed by ray or tubular florets and the number of sterile ray or tubular florets of each capitulum were counted. The regression of seed number or seed set relative to floret number or percentage of tubular florets was determined.

Table 1. Days from unfolding to withering of zinnia pistils.

\begin{tabular}{ll}
\hline \hline Cultivar & Days \\
\hline Kumamotonokagayaki & $35 \mathrm{a}^{2}$ \\
Snowball & $29 \mathrm{~b}$ \\
Purple zem & $27 \mathrm{~b}$ \\
\hline
\end{tabular}

${ }^{\overline{2}}$ Mean separation by Scheffe's test $(\mathrm{P}=0.05)$.

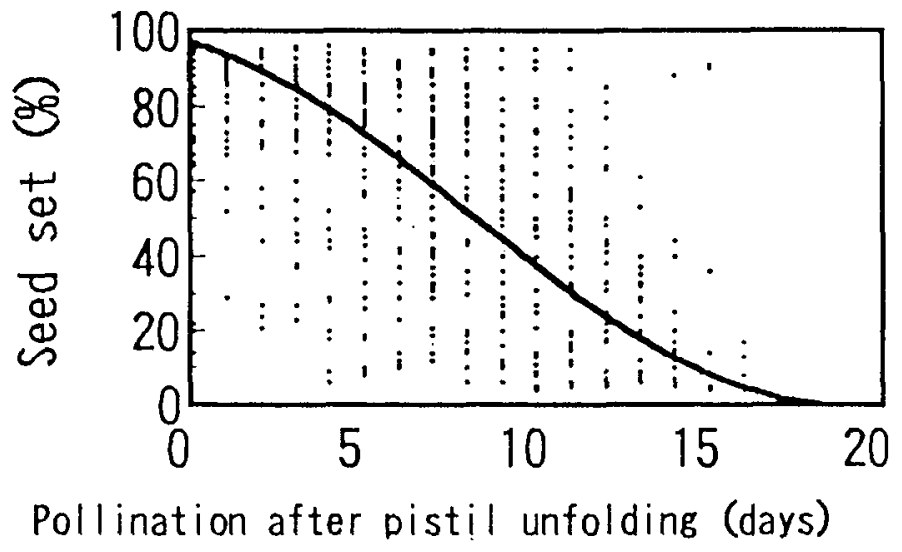

Fig. 1. Seed set of zinnias relative to the days from pistil unfolding to pollination. Data from three cultivars are combined.

Other plant species that affect zinnia pollination. Plant species that were planted or casually grew near zinnias and attracted insects were noted.

\section{Results and Discussion}

Longevity of unpollinated pistils and seed set of ray florets pollinated by hand. Unpollinated pistils remained alive $>23$ days after unfolding (Table 1). ANOVA indicated no significant differences among cultivars and cultivar $\times$ the days from pistil unfolding to pollination for the seed set of ray florets pollinated at various intervals from pistil unfolding (data not shown). Seed set was highly dependent on pistil age at the time of pollination (Fig. 1). Seed set was about $80 \%$ when pollination occurred a few days after pistil unfolding. Based on this result, poor pollination was considered to be a major cause of low seed set of open-pollinated zinnias. Pollination within 5 days from pistil unfolding resulted in high seed set. It gradually decreased with the days from pistil unfolding. In 'Kumamotonokagayaki' and 'Purple zem', the seed set became zero 17 days after pistil unfolding, while in 'Snowball' it became zero 18 days after pistil unfolding. On the other hand, pollen germinated normally on the stigmatic surface 20 days after pistil unfolding (microscopic observation). In fruit trees, ovule longevity, pollen receptivity on stigma, and the speed of growth of the pollen tubes in the style are listed as important factors affecting the possible period for successful pollination and consequently for a successful fruit set (Egea et al., 199 1). Because the ability of zinnia florets to set seed was lowered due to pistil age, a continuous pollen supply synchronizing with opening of the florets is necessary.

Number of pollen grains per tubular floret and pollen-ovule ratio. There were no significant differences in the pollen grain number per tubular floret among the cultivars (Table 2). The pollen grain number per tubular floret was 12,000 to 18,000 . The pollen-

Table 2. Number of pollen grains per tubular floret and pollen-ovuleratios of three zinnia cultivars.

\begin{tabular}{lccc}
\hline \hline & & \multicolumn{2}{c}{ Pollen-ovule ratio } \\
\cline { 3 - 4 } Cultivar & Grains & $\begin{array}{c}\text { Single-flowered } \\
\text { capitulum }\end{array}$ & $\begin{array}{c}\text { Double-flowered } \\
\text { capitulum }\end{array}$ \\
\hline Kumamotonokagayaki & 16,700 & $9,600-15,900$ & $2,940-5,630$ \\
Snowball & 16,600 & $10,600-15,700$ & $2,520-5,180$ \\
Purple zem & 13,800 & $6,960-10,600$ & $2,240-4,270$ \\
& NS & & \\
\hline
\end{tabular}

${ }^{\mathrm{Ns}}$ Nonsignificant by Tukey's studentized range test $(\mathrm{P}>0.05)$. 
ovule ratios were $>2000$, even in double-flowered capitula. Compared with other plant species, the pollen number was considered sufficient for seed production (Cruden, 1975). However, the timing of floret opening in double-flowered capitula causes the pollen to be inefficiently used for pollination (Miyajima and Nakayama, 1994).

Pollen germination. ANOVA indicated that the percentage germination of pollen was significantly different among the cultivars, but they were not different among pollen collection dates. The cultivar $\mathrm{x}$ pollen collection date interaction was not significant either (ANOVA table not shown). Germination percentages were $34 \%, 45 \%$, and $29 \%$ for 'Kumamotonokagayaki', 'Goldenball', and 'Purple zem', respectively (data from 6 days are combined). The maximum percentage achieved was about $50 \%$ (unpublished data). If the percentage germination of pollen on the stigmatic surface was at these levels, the pollen load on a pistil would affect the seed set because pistils do not always accept abundant pollen by open-pollination.

Insect visits to ray and tubular florets. Insect visits per hour were largely different between ray and tubular florets (Table 3). Landing time per visit was also different between the two types of florets. These facts suggested that capitulum types with more tubular florets or less ornamental value attracted more insects than those with, more ray florets or more ornamental value, causing more successful pollination in the former type of capitula. In beans, bee visitation is different between male-fertile and male-sterile plants (Bond and Hawkins, 1967). According to visual observation, honeybees collected nectar and pollen in tubular florets, but they flew away immediately after landing on or touching ray florets. Other bee species acted similarly. Droneflies collected nectar and pollen in tubular florets, but they often walked around for a few seconds or stood still when they landed on ray florets. Because tubular florets open once in a few days in a doubleflowered capitulum (Miyajima and Nakayama, 1994), pollinator visits to the capitulum could decrease on a day when no tubular florets were open in the capitulum.

Pollen load of ray stigmas exposed several times after unfolding in the field. Insects that visited zinnias on the day this study was done were Apis cerana, Apis mellifera, Eristalomyia tenax, Osmia cornifrons, Polistes chinensis, Parnara guttata, and Lucaena phlaeas daimio. Although the density of pollinators in a given area was unknown due to the wide variation, most pollen grains were carried away at 1600 HR on any day. The numbers of pollen grains on stigmatic surfaces differed on different dates (Fig. 2). Stigmas with no pollen accounted for $>50 \%$ of those in any cultivar on 4 Sept., whilethese were at a low percentage on 7 Sept. On any date, the percentage of stigmas loaded with $>10$ pollen grains was low. However, in spite of the low frequency of insect visits to ray florets as previously stated, it was discovered that a considerable percentage of stigmas accepted pollen on the day they unfolded. As previously described, the action of the dronefly is considered to be closely related to the results. On the other hand, the pollen load

Table 3. Number of insect visits to zinnia florets per hour and staying time per visit.

\begin{tabular}{lccccc}
\hline \hline \multirow{2}{*}{ Floret } & \multicolumn{2}{c}{ Visits/h (no.) } & & \multicolumn{2}{c}{ Staying time/visit (sec) } \\
\cline { 2 - 3 } \cline { 5 - 6 } type & Honeybee & Dronefly & & Honeybee & Dronefly \\
\hline Ray & 8 & 9 & & 2 & 4 \\
Tubular & 87 & 76 & & 20 & 40 \\
Significance & $* * z$ & $* *$ & & $* * y$ & $* *$
\end{tabular}

${ }^{\overline{7}}$ Significant by chi-square test for goodness of fit $(P<0.01)$.

${ }^{y}$ Significant by Mann-Whitney test $(P<0.01)$.

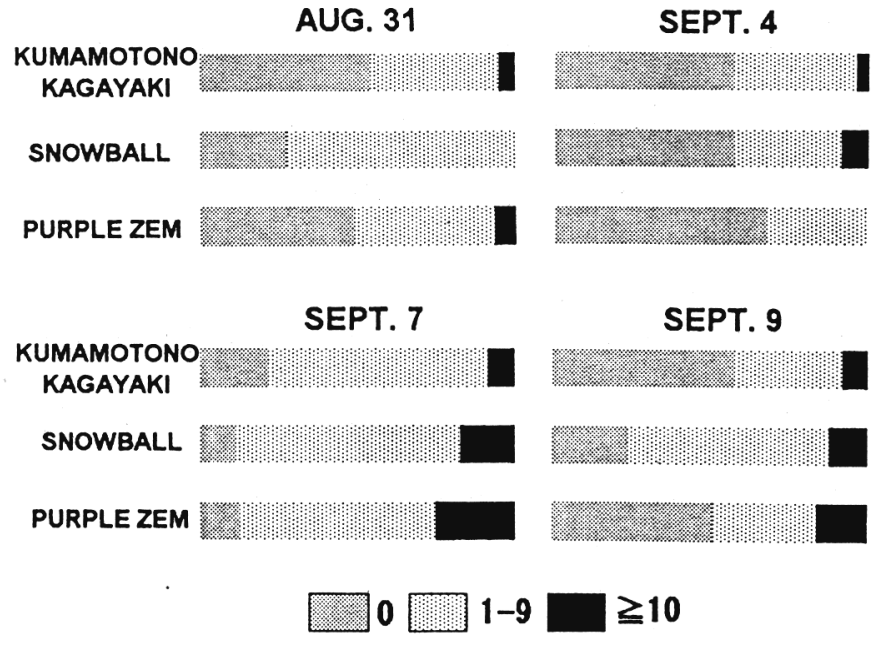

Fig. 2. Percentage of pistils in each of three grades sorted by the number of pollen grains attached to their stigmatic surfaces. Legends denote the number of pollen grains on a stigmatic surface. The percentages are significantly different among cultivars for each date and among the dates by the chi-square test for independence $(P<0.01)$.

differed among cultivars: the percentages of stigmas with no pollen in 'Snowball' (ray petal color white) were relatively low compared with 'Kumamotonokagayaki' (red) and 'Purple zem' (pink purple). The frequency of insect visits differs with the variation in color of the flower: white and yellow are more attractive than other colors (Kobayashi, 1981). This tendency in insect activity may account for the results presented.

Overlapping of petals on pistils. Inflorescence morphology could influence the rate and pattern of pollen movement within plant populations (Wyatt, 1982). Although stigmas could not always receive pollen on the day of their unfolding, the fact that pistils were receptive to pollen over a long period increased the possibility of successful pollination and for the seed to set. However, in double-flowered capitula, some of the pistils were covered with other ray petals on the day following their unfolding (Fig. 3). They were completely covered within a few days after unfolding. Insects never crept into the layer of ray florets, which had no nectar or pollen. In view of this obstruction, the possible periods for successful pollination of ray florets in double flower capitula were reduced to only a few days. In contrast, single-flowered capitula, which were free from such obstructions, were easily pollinated.

Seed production of the two types of florets of open-pollinated plants. The number of total seeds was linearly related to the number of tubular florets in a capitulum (Fig. 4A), but was negatively correlated with the number of ray florets (Fig. 4D). These results show that the more ornamental the capitulum, the fewer seeds it produces. The number of seeds formed by tubular florets was quadratically related to the number of tubular florets (Fig. 4B), while the number of seeds formed by ray florets was independent of the tubular or ray floret number (Fig. $4 \mathrm{C}$ and $\mathrm{E}$ ). The maximum number of seeds formed by ray florets per capitulum was $<100$. The limited number of seeds formed by ray florets of a double- and single-flowered capitulum is attributed to rare visits of insects to the former type and to the low number of ray florets in the latter type. Increase in seed yield with an increase in the number of single-flowered plants is attributed mostly to tubular florets rather than the ray florets. With an increase in the percentage of tubular florets, the seed set increased, but it did not exceed $70 \%$ in any capitulum (Fig. 4F). The seed set of double-flowered capitula with $<30 \%$ tubular florets, the capitulum type of 

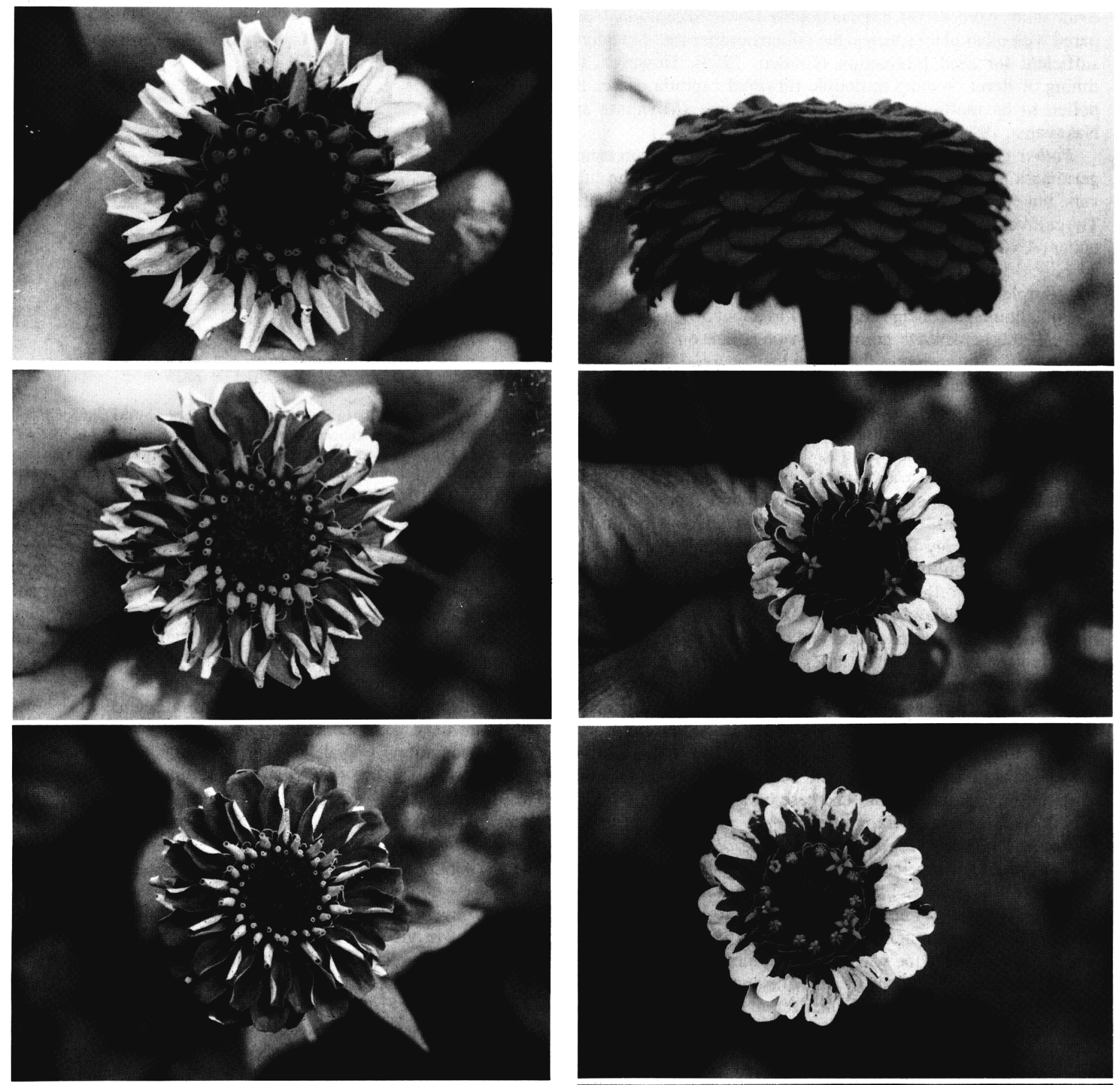

Fig. 3. Comparing a double-flowered with a single-flowered capitulum. (A) First day of flowering in a double-flowered capitulum. Ray petals were painted white to discriminate the petals that opened afterward. Pistils are positioned at the base of the ray petals. (B) Second day of flowering. Newly opened ray petals are overlapping. (C) Third day of flowering. From this angle, the my petals opening on the first day are almost unseen because of those opened afterward. (D) The identical capitulum several days later. Pistils are fully covered by ray petals. (E) First day of floret flowering in a single-flowered capitulum. (F) Second day of flowering. No new ray florets open. (G) Third day of flowering. Tubular florets open.

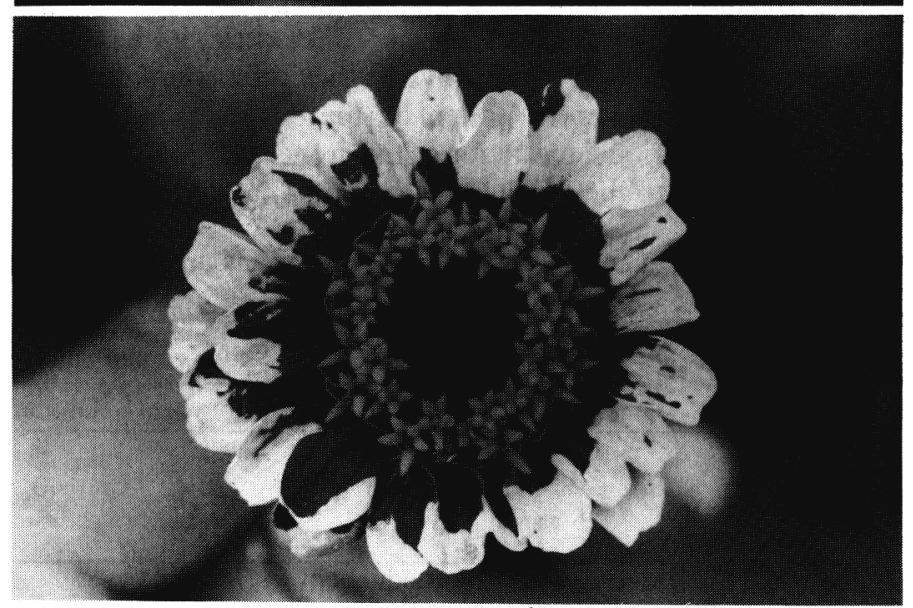




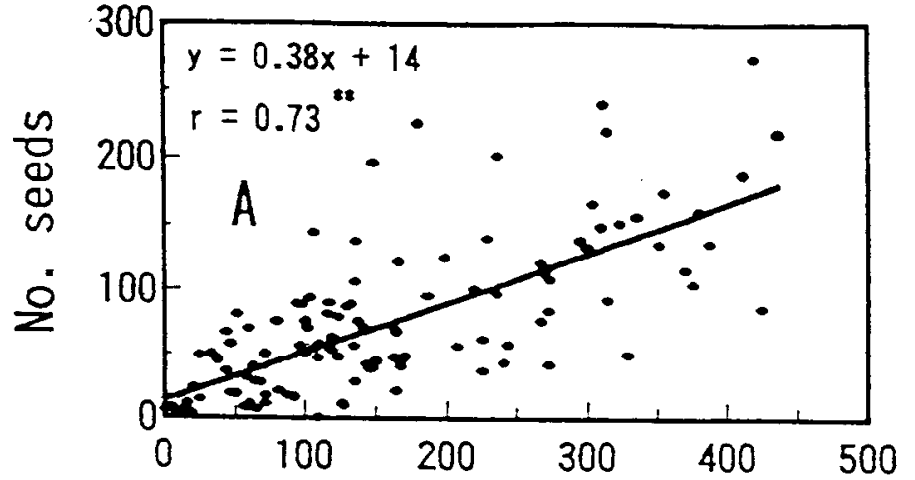

No. tubular florets / capitulum
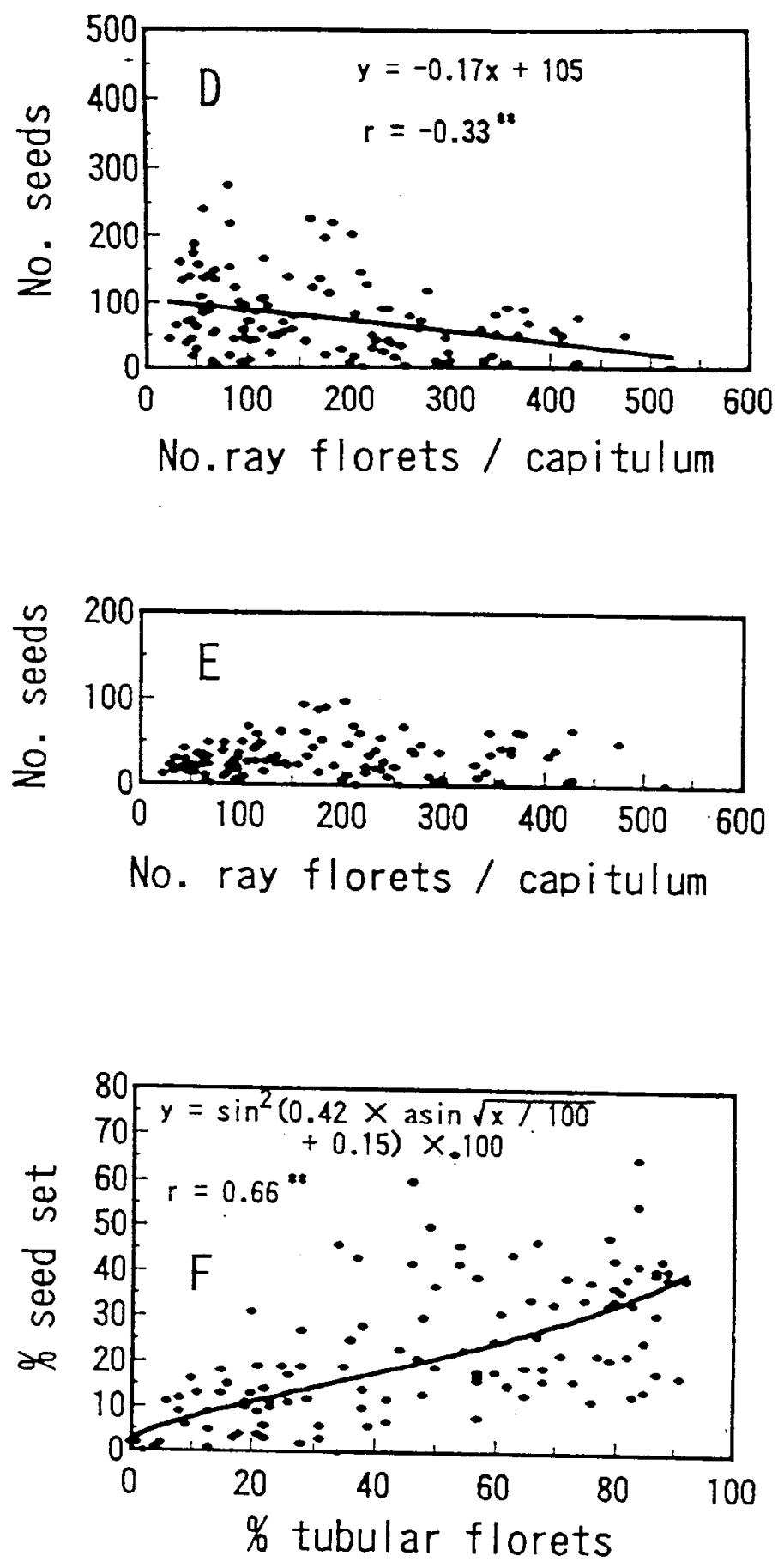

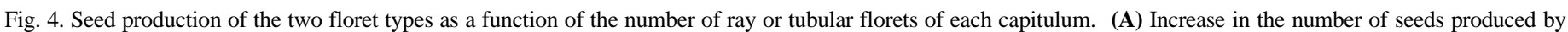

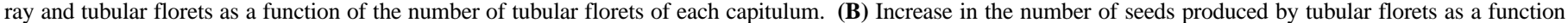

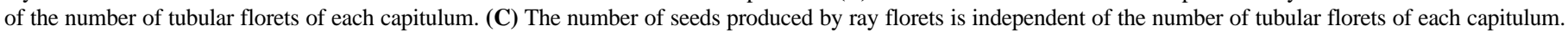
(D) Decrease in the number of seeds produced by ray and tubular florets with an increase in the number of ray florets of each capitulum. (E) The number of seeds produced

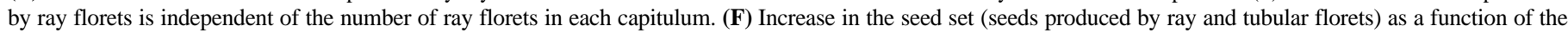
percentage of tubular florets of each capitulum. **,*Significant at $P=0.01$ or 0.05 , respectively. No asteriks means nonsignificant.

'Kumamotonokagayaki', was $30 \%$. These results suggest that seed set increases with increasing density of the single-flowered plants. Based on this, a few methods for increasing the seeds of double-flowered plants and decreasing those of single-flowered plants are suggested as follows.

1) Develop more efficient pollinators than honeybees. Honeybees are the most common and widely distributed pollinators. However, they do not always work effectively (Westerkamp, 1991). For example, the seed yield of alfalfa increases by introducing alfalfa leaf-cutting bees (Bohart, 1970). Bond and Hawkins (1967) recommends bumblebees over honeybees for producing $\mathrm{F}$, hybrid field beans. The present study indicates that droneflies may be more effective pollinators than honeybees for the double-flowered capitula of zinnias.

2) Alter (chemically or environmentally) double-flowered capitula into single-flowered capitula without causing a genetic change. Kim et al. (1989) reported that double-flowered capitula can be changed into single-flowered capitula by applying uniconazole. 
On the other hand, the number of the two types of florets in a capitulum can be changed by day length (Boyle and Stimart, 1983; Okada, 1951). These procedures may be applied to solving seed production problems of double-flowered zinnias.

Otherplant species that affect zinnia $p \&$ nation. Competition for pollinators between crops or between crops and weeds can occur (Free, 1968; Linsley and Macswain, 1947). In the present study, sunflowers (Helianthus annuus) were planted within $30 \mathrm{~m}$ of a zinnia population. Anthesis occurred almost simultaneously in the two plant species. Honeybees frequently visited the sunflowers, resulting in decreased visits to the zinnias. When poppies (Papaver phoeas) wereplanted within $30 \mathrm{~m}$ of a zinnia population, honeybees visited only the poppies. Although honeybees were attracted by Persicaria lapathifolia, which grew among zinnias, the honeybees did not visit the zinnias during the anthesis of this weed. Thus, some plant species around zinnias affected their pollination. Honeybees show preferences for some plant species (Wykes, 1952). The attraction depends on the amount and the concentration of sugars in the nectar (Butler, 1945; Vansell, 1934). There are no reports that indicate the existence of insects that are monotropic to zinnias, so seed production in zinnias depends on insects that visit various kinds of plants. Flower constancy is a typical habit of bees (Grant, 1950). If plants that attract bees more than zinnias exist close to zinnias, the bees will not visit the zinnias. Therefore, plant species around zinnias must be considered if zinnias are grown for seed production. In addition, eradication of weeds that attract pollinators more than zinnias is important.

\section{Conclusions}

In addition to previous results (Miyajima and Nakayama, 1994), factors limiting seed set in double-flowered zinnias were the infrequent insect visits to ray florets and the overlapping of newly opened ray petals. Although a considerable percentage of ray pistils accepted pollen on the day of their unfolding, the pollen load was small and the actual seed set was low. Therefore, improving the pollination of double-flowered capitula is important in solving seed production problems of double-flowered zinnias.

\section{Literature Cited}

Bohart, G.E. 1970. Commercial production and management of wild bees: A new entomological industry. Bul. Entomol. Soc. Amer. 168-9.

Bond, D.A. and R.P. Hawkins. 1967. Behaviour of bees visiting malesterile field beans (Vicia faba). J. Agr. Sci. Cambridge 68:243-247.

Boyle, T.H. and D.P. Stimart. 1983. Development responses of zinnia to photoperiod. J. Amer. Soc. Hort. Sci. 108:1053-1059.

Butler, C.G. 1945. Influence of various physical and biological factors of the environment on honeybee activity. An examination of the relationship between activity and nectar concentration and abundance. J. Expt. Biol. 21:5-12.

Cruden, R.W. 1975. Pollen ovule ratios: A conservative indicator of breeding systems in flowering plants. Evolution 31:3246.

Egea, J., L. Burgos, J.E. Garcia, and L. Egea. 1991. Stigmareceptivity and style performance in several apricot cultivars. J. Hort. Sci. 66: 19-25.

Free, J.B. 1968. Dandelion as a competitor to fruit trees for bee visits. J. Applied Ecol. 5:169-178.

Grant, V. 1950. The flower constancy of bees. Bot. Rev. 8379-397.

Kim, H.Y ., T. Abe, H. Watanabe, and Y. Suzuki. 1989. Changes in flower bud development of Zinnia elegans Jacq. as influenced by the growth retardant S-07. J. Hort. Sci. 64:81-89.

Kobayashi, M. 1981. Shikisaitohoukakontyuu, p. 10. In: Engeisakumotsunojyufuntokafunbaikaikontyuu-sonozoushokutoriyou. Seibundoushinkousha Publ. Corp., Tokyo.

Linsley, J.W. and J.W. Macswain. 1947. Factors influencing the effectiveness of insect pollnators of alfalfa in California. J. Econ. Entomol. 40:349-357.

Miyajima, D. and M. Nakayama. 1994. Analysis of zinnia capitulum composition. J. Amer. Soc. Hort. Sci. 119:683-486.

Okada, M. 1951. Jinianosaishunikansuru 2,3 nojikken. Nogyo oyobi engei. 26:984-986.

Sokal, R.R. and F.J. Rohlf. 1981. Biometry. Freeman, New York.

Vansell, G.H. 1934. Relation between the nectar concentration in fruit blossoms and the visits of honeybees. J. Econ. Entomol. 27:943-945.

Westerkamp, C. 1991. Honeybees are poor pollinators-Why? Plant Syst. Evol. 177:71-75.

Wyatt, R. 1982. Inflorescence architecture: How flower number, arrangement, and phenology affect pollination and fruit set. Amer. J. Bot. 69:585-594.

Wykes, G.R. 1952. The preferences of honeybees for solutions of various sugars which occur in nectar. J. Expt. Biol. 29:511-519. 